dr Anetta Zielińska

Academy of Economics in Woclaw

Faculty of Regional Economy and Tourism in Jelenia Gora

Department of Governing Quality and Environment

St. Nowowiejska 3

58 - 500 Jelenia Gora, Poland

\title{
EUROPEAN UNION FOUNDS FOR SUSTAINED TOURISM
}

\begin{abstract}
The implementation of sustainable tourism is connected with pro-environmental investments, which require meaningful finances. For the aim it is important to use those resources which come from European Union support, such as European Agricultural Fund for Rural Development, European Regional Development Fund, European Social Founds, Integrated Operational Program for Regional Development.
\end{abstract}

Key words: sustainable tourism, European Union founds 